\title{
Positive self-perceived health of octogenarians participating in community groups
}

\author{
Autopercepção positiva de saúde de indivíduos octogenários \\ participantes de grupos de convivência
}

Rodrigo de Rosso Krug', Giovana Zarpellon Mazo², Ione Jayce Ceola Schneider³, Susana Cararo Confortin ${ }^{4}$, Marize Amorim Lopes 5 , Danielle Ledur Antes ${ }^{4}$, Maruí Weber Corseuil Giehl', André Junqueira Xavier ${ }^{4}$, Eleonora d'Orsi'

\begin{abstract}
The aim of this study was to analyze the factors associated with positive self-perceived health of octogenarians participating in community groups in the city of Florianópolis, Southern Brazil. A cross-sectional study was conducted with 343 older adult individuals aged 80 years or older, of both sexes, participating in community groups. A questionnaire was applied through a face-to-face interview, including socio-demographic and economic data, self-reported health status, falls, lifestyle and leisure domain from the International Physical Activity Questionnaire. Poisson regression was used to identify the factors associated with positive self-perceived health, adjusted for socio-demographic, economic, behavioral, health condition and fall variables. The prevalence of positive self-perceived health among octogenarians was $49.0 \%$ (95\%CI=44.0-54.0). The factors associated with positive self-perceived health were as follows: to receive a monthly income higher than six minimum wages $(\mathrm{PR}=1.39$; $95 \% \mathrm{CI}=1.01$ $2.11)$, to smoke currently $(\mathrm{PR}=1.75 ; 95 \% \mathrm{CI}=1.25-2.46)$, to be physically active during leisure time $(\mathrm{PR}=1.33$; $95 \% \mathrm{CI}=1.06$ 1.67), to have arthritis or rheumatism $(\mathrm{PR}=0.55$; $95 \% \mathrm{CI}=0.37$ $0.80)$, diabetes $(\mathrm{PR}=0.54 ; 95 \% \mathrm{CI}=0.37-0.79)$ and cardiovascular disease $(\mathrm{PR}=0.71 ; 95 \% \mathrm{CI}=0.53-0.95)$, apart from using medications ( $\mathrm{PR}=0.74 ; 95 \% \mathrm{CI}=0.60-0.91)$. Thus, it could be concluded that some modifiable factors were identified, such as income, smoking, leisure physical activity, and use of medications, which can interfere with the positive self-perceived health of octogenarians participating in community groups.
\end{abstract} Keywords

Aged, 80 and over; Health; Comorbidity; Lifestyle.

\section{Resumo}

$O$ objetivo deste estudo foi analisar os fatores associados à autopercepção positiva de saúde de octogenários participantes de grupos de convivência de Florianópolis. Estudo transversal com 343 idosos com 80 anos ou mais, de ambos os sexos, participantes de grupos de convivência. Aplicou-se um questionário em forma de entrevista face a face contendo dados sociodemográficos, econômicos, autorrelato do estado de saúde, quedas, estilo de vida e o domínio de lazer do Questionário Internacional de Atividade Física. Para identificar os fatores associados à autopercepção positiva de saúde, utilizou-se regressão de Poisson, ajustada por variáveis sociodemográficas e econômicas, comportamentais, condições de saúde e quedas. A prevalência de autopercepção positiva de saúde dos octogenários foi de 49,0\% (IC95\% = 44,0-54,0). Os fatores associados à autopercepção positiva de saúdeforam receber renda mensal maior que 6 salário mínimos ( $R P=1,39$; IC95\%=1,012,11), fumar atualmente ( $R P=1,75$; IC95\%=1,25-2,46), ser fisicamente ativo no lazer $(R P=1,33$; IC95\% $=1,06-1,67)$, o autorrelato de artrite ou reumatismo $(R P=0,55$; $I C 95 \%=0,37-0,80)$, de diabetes $(R P=0,54 ; I C 95 \%=0,37-0,79)$ e de doenças cardiovasculares $(R P=0,71 ; I C 95 \%=0,53-0,95)$, além de, fazer uso de medicamento $(R P=0,74 ;$ IC95\%=0,60-0,91). Assim, conclui-se que foram detectados alguns fatores modificáveis, tais como renda, tabagismo, atividade física no lazer, uso de medicamento, que podem interferir na autopercepção positiva de saúde de octogenários participantes de grupos de convivência.

\section{Palavras-chave}

Idoso de 80 anos ou mais; Saúde; Comorbidade; Estilo de vida
1 Federal University of Santa Catarina (UFSC), Graduate Program in Medical Sciences (PPGCM), Florianópolis, SC, Brazil.

2 University of Santa Catarina State (UDESC), Graduate Program in Human Movement Sciences (PPGCMH), Florianópolis, SC, Brazil.

3 Federal University of Santa Catarina (UFSC), Undergraduate Course in Physiotherapy, Araranguá, SC, Brazil.

4 Federal University of Santa Catarina (UFSC), Graduate Program in Collective Health (PPGSC), Florianópolis, SC, Brazil.

5 Federal University of Santa Catarina (UFSC), Sports Center (CDS), Florianópolis, SC, Brazil.

\section{Introduction}

The world is undergoing a demographic transition caused by the advances in the area of health (early diagnoses of diseases and greater effectiveness of drugs and treatments), improvement in public health mea- 
sures (vaccination and basic sanitation) and reduction in birth, fertility and mortality rates ${ }^{1}$. This set of factors is increasing the life expectancy of the population ${ }^{1,2}$. The age group of 80 years and older, known as octogenarians, is the one increasing the most ${ }^{1,3}$. It is estimated that this population will total 379 million individuals worldwide ${ }^{2}$ and more than 14 million in Brazil ${ }^{3}$ by 2050 . Approximately $0.3 \%$ of these older adult individuals live in the city of Florianópolis, Southern Brazil ${ }^{3}$.

Octogenarians have different characteristics when compared to other age groups, such as worse social conditions and a higher prevalence of disabilities, restrictions and diseases, especially chronic ones ${ }^{2,3}$. The most frequent diseases in this group are arterial hypertension, stroke, cancer, cardiovascular diseases, hypercholesterolemia and arthritis ${ }^{3}$. In this sense, health care in this age group is one of the greatest challenges of public health ${ }^{3}$.

The aging process, apart from causing several health and social problems, is also associated with a negative perception of health ${ }^{4,5}$. This fact can be explained by self-perceived health being associated with good physical, cognitive and emotional aspects, in addition to a feeling of well-being and satisfaction with life $e^{4,5}$.

In Brazil, older adult community groups are an alternative to social promotion and health care. These groups primarily aim to increase social participation and interaction among older adults 6 . Older adult individuals participating in community groups usually have better health and social interaction and a more active lifestyle ${ }^{7}$.

Considering the fact that the majority of studies focus on a negative perception of health ${ }^{4}$, that few investigate this theme in octogenarians participating in community groups, and that the identification of the factors associated with this can help to improve preventive and rehabilitating health actions for the population of older adults aged 80 years and more, the present study aimed to analyze the factors associated with positive self-perception of health among octogenarians participating in community groups in the city of Florianópolis.

\section{Methods}

\section{Study design}

A cross-sectional study was performed in the city of Florianópolis, state of Santa Catarina, Southern Brazil, with a population of older adult individuals of both sexes, aged 80 years and more (octogenarians) ${ }^{3}$, participating in older adult community groups registered with the Florianópolis City Hall.

Older adult community groups are based on educational practices developed in groups, aimed at participatory education, according to the perspective that everyone is active in the group work ${ }^{6}$. Manual activities such as knitting, crochet, sewing, recreational activities such as bingo, card games and dominoes; educational activities such as lectures and courses; and leisure activities such as tourist trips, balls and physical activities and snacks are developed in these older adult community groups. These groups usually meet once a week ${ }^{6}$.

\section{Population and sample}

The population of the present study was comprised of older adult individuals aged 80 years and more, of both sexes, registered with older adult community groups of the Florianópolis City Hall in 2010. A total of 497 octogenarians registered with such groups were found. However, those who accepted to participate in this research project voluntarily on the data collection days were included in it $(n=343)$. Only one visit was made to each of the 102 older adult community groups of Florianópolis. The present study was performed from August 2010 to 
April 2011. A total of 19 individuals refused to participate, eight were excluded due to missing data and 127 were absent on the data collection days.

\section{Instruments and data collection}

Instruments were applied by previously trained researchers through face-to-face interviews, which were filled out in forms and subsequently tabulated in the Microsoft Excel software.

Self-perceived health was assessed through the following question: "In general, would you say your health is: very good, good, fair, poor, or very poor? ${ }^{8}$. For the analysis, the outcome was divided into positive ("very good" and "good") and negative ("fair", "poor", "very poor")'.

The following covariables were analyzed: age (in years), sex (male/female), marital status (married/cohabiting, single, divorced/separated, widowed), family arrangement (living alone/with others), level of education (illiterate, incomplete primary education, complete primary education, complete secondary education, higher education), ethnicity (white, black/mixed/Asian descendant), current employment (working/not working), income in minimum wages $(<1$ wage, 1 to 3 wages, 3 to 6 wages, $>6$ wages), self-reported spine disease (yes, no), arthritis and/ or rheumatism (yes, no), cancer (yes, no), bronchitis and/or asthma (yes, no), stroke (yes, no), stomach ulcer (yes, no), urinary incontinence (yes, no), use of medication (yes, no), falls in the previous year (yes, no) and tobacco use (non-smoker, smoked and stopped, current smoker).

Alcohol use (no, moderate/high) was assessed with three questions from the Alcohol Use Disorders Identification Test (AUDIT) ${ }^{10}$. Older adult individuals who do not consume alcohol were considered as "no"; those who consume a dose or less with any frequency, "moderate"; and those who usually consumed five or more doses or two or more doses when drinking, "high". Current employment (yes, no) was assessed through the following question: "Do you have a paid job at the moment?". Physical activity level during leisure time was evaluated with the International Physical Activity Questionnaire (IPAQ), version 8, long form and normal week, adapted to older adults ${ }^{11}(<150$ minutes per week, $\geq 150$ minutes per week).

For the instruments to be applied, the Florianópolis City Hall was initially contacted, so as to obtain access to the number of registered older adult community groups, their addresses, and data to contact group coordinators. Subsequently, community group coordinators were contacted to request permission for the research project to be performed. Next, octogenarians were contacted in the community groups of which they were members and invited to participate in this project. Finally, the date and time of interviews were scheduled and the research instrument was applied.

\section{Data analysis}

Descriptive analysis was performed to identify the sample characteristics. The normality of continuous data was tested and a $\mathrm{p}$-value $\leq 0.05$ was considered to be significant.

For the identification of factors associated with positive self-perceived health, crude and adjusted analysis was performed with Poisson regression. Variables showing a p-value higher than 5\% were included in the model in steps; first, the socio-demographic and economic variables; second, the behavioral variables; third, health conditions; and, finally, falls in the previous year. All variables were included in their specific step in the adjusted analysis. In the first step, variables show- 
ing an association with the outcome ( $\mathrm{p}$-value $\leq 0.05$ ) adjusted the second step. The third step was adjusted by the significant variables from the first step and those with a $\mathrm{p}$-value $\leq 0.05$ from the second step. A p-value $\leq 0.05$ was considered to be significant. STATA SE software, version 11.0 (Stata Corporation, College Station, United States), was used in all analyses.

\section{Ethical aspects}

All ethical principles for research were met, in accordance with the current resolution from the National Health Council. The present study was approved by the Human Research Ethics Committee (protocol 149/2010). All participants had to sign an informed consent form. Authors declared no conflicts of interest.

\section{Result}

The study sample was comprised of 343 octogenarians with a mean age of $84.1 \pm 3.9$ years. The prevalence of positive self-perceived health was $49.0 \%$ (95\% CI= 44.054.0) (Table 1).

The majority of octogenarians were females (91.8\%) and widowed (77.6\%), lived with someone $(66.2 \%)$, did not complete primary education $(55.7 \%)$, were white (94.2\%), did not have a paid and/or volunteer job (97.7\%) and received less than three minimum wages (60.4\%). Regarding health conditions, the majority had arterial hypertension (59.8\%) and used at least one medication daily (88.9\%). In terms of life habits, most had never smoked (89.8\%) did not consume alcohol (100\%), had not fallen in the previous year $(68.2 \%)$ and were physically inactive during leisure time (80.8\%) (Table 1).

After the adjusted analysis, Table 2 showed that the factors associated with positive self-perceived health were as follows: to receive a monthly income higher than six minimum wages $(\mathrm{PR}=1.39 ; 95 \% \mathrm{CI}=0.91-2.11)$, to be smoking currently $(\mathrm{PR}=1.75 ; 95 \% \mathrm{CI}=1.25-2.46)$, to be physically active during leisure time $(\mathrm{PR}=1.33$; $95 \% \mathrm{CI}=1.06-1.67)$, to report arthritis or rheumatism $(\mathrm{PR}=0.55 ; 95 \% \mathrm{CI}=0.37$ $0.80)$, diabetes $(\mathrm{PR}=0.54 ; 95 \% \mathrm{CI}=0.37-0.79)$ and cardiovascular diseases $(\mathrm{PR}=0.71$; $95 \% \mathrm{CI}=0.53-0.95)$, and to use medications $(\mathrm{PR}=0.74 ; 95 \% \mathrm{CI}=0.60-0.91)$.

TABLE 1 - Socio-demographic, health and behavioral characteristics of octogenarians participating in community groups of the city of Florianópolis, Southern Brazil, 2011 ( $n=343)$.

\begin{tabular}{lc}
\hline Variables & $n(\%)$ \\
\hline Self-perceived health & \\
\hline Positive & $168(49.0)$ \\
\hline Negative & $175(51.0)$ \\
\hline Sex & \\
\hline Female & $315(91.8)$ \\
\hline Male & $28(8.2)$ \\
\hline Marital Status & $47(13.7)$ \\
\hline Married/Cohabiting & $19(5.5)$ \\
\hline Single & $11(3.2)$ \\
\hline Divorced/separated & $266(77.6)$ \\
\hline Widowed & $116(33.8)$ \\
\hline Family arrangement & $227(66.2)$ \\
\hline Lives alone & \\
\hline Lives with other people & \\
\hline
\end{tabular}

Continue... 
... continue

\begin{tabular}{|c|c|}
\hline \multicolumn{2}{|l|}{ Level of education } \\
\hline Illiterate & $44(12.8)$ \\
\hline Incomplete primary education & $191(55.7)$ \\
\hline Complete primary education & $52(15.2)$ \\
\hline Complete secondary education & $42(12.2)$ \\
\hline Higher education & $14(4.1)$ \\
\hline \multicolumn{2}{|l|}{ Ethnicity } \\
\hline White & $323(94.2)$ \\
\hline Black/mixed/Asian descendant & $20(5.8)$ \\
\hline \multicolumn{2}{|l|}{ Employment status } \\
\hline Not working & $335(97.7)$ \\
\hline Working & $8(2.3)$ \\
\hline \multicolumn{2}{|l|}{ Income } \\
\hline$<1$ minimum wage & $40(11.7)$ \\
\hline 1 to 3 minimum wages & $167(48.7)$ \\
\hline 3 to 6 minimum wages & $30(8.7)$ \\
\hline$>6$ minimum wages & $106(30.9)$ \\
\hline \multicolumn{2}{|l|}{ Spine disease } \\
\hline No & $332(96.8)$ \\
\hline Yes & $11(3.2)$ \\
\hline \multicolumn{2}{|l|}{ Arthritis/rheumatism } \\
\hline No & $240(70.0)$ \\
\hline Yes & $103(30.0)$ \\
\hline \multicolumn{2}{|l|}{ Diabetes } \\
\hline No & $269(78.4)$ \\
\hline Yes & $74(21.6)$ \\
\hline \multicolumn{2}{|l|}{ Bronchitis/Asthma } \\
\hline No & $329(95.9)$ \\
\hline Yes & $14(4.1)$ \\
\hline \multicolumn{2}{|l|}{ Hypertension } \\
\hline No & $138(40.2)$ \\
\hline Yes & $205(59.8)$ \\
\hline \multicolumn{2}{|l|}{ Cardiovascular diseases } \\
\hline No & $252(73.5)$ \\
\hline Yes & $91(26.5)$ \\
\hline \multicolumn{2}{|l|}{ Depression } \\
\hline No & $332(96.8)$ \\
\hline Yes & $11(3.2)$ \\
\hline \multicolumn{2}{|l|}{ Stroke } \\
\hline No & $339(98.8)$ \\
\hline Yes & $4(1.2)$ \\
\hline \multicolumn{2}{|l|}{ Stomach ulcer } \\
\hline No & $337(98.2)$ \\
\hline Yes & $6(1.8)$ \\
\hline \multicolumn{2}{|l|}{ Urinary incontinence } \\
\hline No & $333(97.1)$ \\
\hline Yes & $10(2.9)$ \\
\hline Use of medication & \\
\hline
\end{tabular}

Continue... 
... continue

\begin{tabular}{lc}
\hline No & $38(11.1)$ \\
\hline Yes & $305(88.9)$ \\
\hline Tobacco use & $308(89.8)$ \\
\hline No & $33(9.6)$ \\
\hline Smoked and stopped & $2(0.6)$ \\
\hline Smokes currently & $343(100.0)$ \\
\hline Alcohol use & $0(0.0)$ \\
\hline No & $277(80.8)$ \\
\hline Moderate/high & $66(19.2)$ \\
\hline Physical activity level during leisure time & \\
\hline$<150$ minutes per week & $234(68.2)$ \\
\hline$\geq 150$ minutes per week & $109(31.8)$ \\
\hline Falls in the previous year & \\
\hline No & \\
\hline Yes & \\
\hline
\end{tabular}

$\mathrm{n}=$ absolute frequency; \%= relative frequency; Value used to convert the crude family income variable: $\mathrm{R} \$ 510.00$

TAB LE 2 - Crude and adjusted analysis of the factors associated with positive self-perceived health of octogenarians participating in community groups of the City of Florianópolis, Southern Brazil, 2011 ( $n=343$ ).

\begin{tabular}{|c|c|c|c|c|c|}
\hline \multirow{2}{*}{ Variables } & \multirow{2}{*}{$\begin{array}{c}\text { Positive } \\
\text { self-perceived } \\
\text { health (\%) }\end{array}$} & \multicolumn{2}{|c|}{ Crude analysis } & \multicolumn{2}{|c|}{ Adjusted analysis } \\
\hline & & PR $(95 \% \mathrm{Cl})$ & $p$-value & PR $(95 \% C l)$ & p-value \\
\hline Age & -- & $1.00(0.97-1.03)$ & 0.948 & $1.00(0.97-1.03)$ & 0.980 \\
\hline Sex & & & 0.597 & & 0.668 \\
\hline Female & 45.9 & 1 & & 1 & \\
\hline Male & 46.3 & $1.10(0.77-1.59)$ & & $1.10(0.72-1.67)$ & \\
\hline Marital status & & & 0.671 & & 0.507 \\
\hline Married/cohabiting & 46.4 & 1 & & 1 & \\
\hline Single & 53.6 & $1.07(0.64-1.80)$ & & $1.19(0.71-1.99)$ & \\
\hline Separated/divorced & 50.0 & $0.56(0.20-1.53)$ & & $0.55(0.21-1.46)$ & \\
\hline Widowed & 45.2 & $1.01(0.74-1.40)$ & & $1.06(0.77-1.46)$ & \\
\hline Family arrangement & & & 0.681 & & 0.573 \\
\hline Lives alone & 47.2 & 1 & & 1 & \\
\hline Lives with other people & 45.6 & $1.05(0.83-1.32)$ & & $1.07(0.84-1.36)$ & \\
\hline Level of education & & & 0.241 & & 0.195 \\
\hline Illiterate & 35.2 & 1 & & 1 & \\
\hline Incomplete primary education & 45.1 & $1.21(0.83-1.78)$ & & $1.20(0.82-1.75)$ & \\
\hline Complete primary education & 47.5 & $1.22(0.78-1.91)$ & & $1.20(0.77-1.87)$ & \\
\hline Complete primary education & 56.5 & $1.10(0.68-1.80)$ & & $1.12(0.69-1.81)$ & \\
\hline Higher education & 52.9 & $1.75(1.07-2.84)$ & & $1.74(1.10-2.77)$ & \\
\hline Ethnicity & & & 0.724 & & 0.770 \\
\hline White & 47.2 & 1 & & 1 & \\
\hline Black/mixed/Asian descendant & 33.3 & $0.91(0.56-1.50)$ & & $0.93(0.57-1.52)$ & \\
\hline Income & & & $0.046^{*}$ & & $0.046^{*}$ \\
\hline$<1$ minimum wage & 38.1 & 1 & & & \\
\hline 1 to 3 minimum wages & 45.2 & $1.15(0.76-1.74)$ & & $1.15(0.76-1.74)$ & \\
\hline 3 to 6 minimum wages & 46.5 & $1.33(0.80-2.21)$ & & $1.33(0.80-2.21)$ & \\
\hline$>6$ minimum wages & 47.7 & $1.39(1.01-2.11)$ & & $1.39(1.01-2.11)$ & \\
\hline
\end{tabular}

Continue... 
continue

\begin{tabular}{|c|c|c|c|c|c|}
\hline \multirow{2}{*}{ Variables } & \multirow{2}{*}{$\begin{array}{c}\text { Positive } \\
\text { self-perceived } \\
\text { health (\%) }\end{array}$} & \multicolumn{2}{|c|}{ Crude analysis } & \multicolumn{2}{|c|}{ Adjusted analysis } \\
\hline & & PR (95\%Cl) & $p$-value & PR $(95 \% C l)$ & p-value \\
\hline Arthritis/rheumatism & & & $<0.001^{*}$ & & $<0.001^{*}$ \\
\hline No & 51.9 & 1 & & 1 & \\
\hline Yes & 34.4 & $0.55(0.40-0.75)$ & & $0.55(0.37-0.80)$ & \\
\hline Diabetes & & & $<0.001^{*}$ & & $0.002^{*}$ \\
\hline No & 51.4 & 1 & & 1 & \\
\hline Yes & 26.4 & $0.49(0.33-0.73)$ & & $0.54(0.37-0.79)$ & \\
\hline Hypertension & & & 0.230 & & 0.798 \\
\hline No & 48.0 & 1 & & 1 & \\
\hline Yes & 44.8 & $0.88(0.71-1.09)$ & & $1.03(0.80-1.34)$ & \\
\hline Cardiovascular diseases & & & $0.010^{*}$ & & $0.021^{*}$ \\
\hline No & 50.6 & 1 & & 1 & \\
\hline Yes & 35.8 & $0.68(0.50-0.91)$ & & $0.71(0.53-0.95)$ & \\
\hline Use of medication & & & $<0.001^{*}$ & & $0.005^{*}$ \\
\hline No & 74.5 & 1 & & 1 & \\
\hline Yes & 43.3 & $0.57(0.47-0.70)$ & & $0.74(0.60-0.91)$ & \\
\hline Tobacco use & & & $<0.001^{*}$ & & $<0.002$ \\
\hline No & 46.6 & 1 & & 1 & \\
\hline Smoked and stopped & 41.7 & $0.79(0.51-1.23)$ & & $0.79(0.51-1.24)$ & \\
\hline Smokes currently & 70.0 & $2.01(1.80-2.25)$ & & $1.75(1.25-2.46)$ & \\
\hline Physical activity level during & time & & $0.003^{*}$ & & $0.013^{*}$ \\
\hline$<150$ minutes per week & 42.8 & 1 & & 1 & \\
\hline$\geq 150$ minutes per week & 61.0 & $1.40(1.12-1.75)$ & & $1.33(1.06-1.67)$ & \\
\hline Falls in the previous year & & & $0.039 *$ & & 0.237 \\
\hline No & 47.8 & 1 & & 1 & \\
\hline Yes & 41.8 & $0.76(0.59-0.99)$ & & $0.86(0.68-1.10)$ & \\
\hline
\end{tabular}

$\mathrm{PR}=$ prevalence ratio; $95 \% \mathrm{Cl}=95 \%$ confidence interval; * $=$ level of significance lower than 5\%.

\section{Discussion}

In the present study, the prevalence of positive self-perceived health of octogenarians participating in community groups of the city of Florianópolis was $49.0 \%$ $(95 \% \mathrm{CI}=44.0-54.0)$. A population-based cross-sectional study performed by Confortin et al. ${ }^{9}$ with 1705 older adult residents in Florianópolis aged 60 years and more observed a prevalence of $51.2 \%$ of positive self-perceived health. A German study conducted by Moschny et al. ${ }^{12}$, which followed 1,937 older adult Germans aged between 72 and 93 years for seven years, showed that individuals aged 80 years and more perceived their health to be poorer, compared to younger individuals.

The use of medication and self-report of certain chronic diseases (arthritis or rheumatism, diabetes and cardiovascular diseases) were associated with the prevalence of positive self-perceived health. On the other hand, older adult individuals who received a monthly income higher than six minimum wages, smoked and were physically active during leisure time had a more positive self-perceived health.

Certain chronic diseases were inversely associated with positive self-perceived health. Octogenarians who self-reported the presence of arthritis/rheumatism showed a lower prevalence of positive self-perceived health when compared to older adults without such conditions. Similar results were found by Loyola Filho et al. ${ }^{13}$ in a study performed with older adult individuals from Bambuí, in the state of 
Minas Gerais. Rheumatism is a disease that affects the joints, causes pain and joint stiffness, in addition to being pointed out as one of the chronic conditions that most frequently restrict one from performing activities, especially those related to self-care and mobility ${ }^{14}$, which can explain the association found in this study.

Octogenarians who self-reported diabetes had a lower prevalence of positive self-perceived health when compared to older adult individuals without such condition. A fact that can be influenced in this association is that older adult individuals at a more advanced age end up becoming more resistant to degenerative processes as they have more functional limitations and morbidities than younger older adult individuals, thus comprising a "biological elite" because, at this age, they succeeded in overcoming child mortality, infectious diseases and chronic degenerative diseases ${ }^{15}$. Thus, even when having any type of disease, octogenarians perceive their health positively due to psychological factors. Studies show that the level of satisfaction with health is usually high among older adult Brazilians, especially in this age group ${ }^{16,17}$.

With regards to the negative association between positive self-report of cardiovascular diseases and positive self-perceived health, this finding corroborates those from other authors that the presence of chronic diseases such as cardiovascular ones can result in difficulties or even restrictions to routine activities of daily living, which influences self-perceived health among older adult individuals ${ }^{12,13}$.

Additionally, it was evidenced that the association between positive self-perceived health and older adult individuals who do not use medication is also indicated by other studies. A study performed with older adult individuals from the state of Minas Gerais found an association between use of medication and reports of poorer self-perceived health ${ }^{18}$, a fact that was also reported among older adult Finnish ${ }^{19}$. According to Loyola Filho et al. ${ }^{18}$, this association can be explained by the relationship between health problems and use of medication, as individuals seek health services when they are or perceive themselves to be ill, aiming to alleviate or solve their problem and receiving drug prescriptions as treatment.

Regarding the results of the association between receiving a monthly income higher than six minimum wages and positive self-perceived health found in this study, other studies that have investigated this theme in older adult Brazilians also found such association ${ }^{4,20,21}$. According to some studies ${ }^{22,23}$, this association can be attributed to the fact that individuals with a higher income have healthier behavior, as they seek health services more frequently and show better adherence to treatments, thus having a direct impact on older adult individuals' health perception.

Regarding behavioral factors associated with the outcome investigated, positive self-perceived health was associated with current smoking. Previous studies ${ }^{5,24}$ found an association between smoking and poorer health perception, in contrast with the findings from the present study. This can be explained by the fact that older adult individuals who are experiencing the disease process tend to stop their smoking habit ${ }^{25,26}$. Thus, older adult individuals who currently smoke tend to have a better self-perceived health.

With regards to behavior associated with physical activity practice during leisure time, it was positively associated with positive self-perceived health. This finding is in agreement with the literature, which shows that more active individuals perceive their health to be more positive, when compared to those who are less ac$\operatorname{tive}^{20,27}$. Moreover, this finding may also have been due to the fact that older adult individuals in this group participate in community groups, as it has been proved 
that those participating in such groups are more physically active in all domains?

Thus, the regular practice of physical activities can help to prevent several diseases and chronic conditions, improve one's ability to perform activities of daily living, and bring psychological and social benefits, factors that can have an influence on a more positive self-assessment of health ${ }^{28,29}$.

It should be emphasized that the present study has some limitations, among which are the use of a cross-sectional design, which does not allow cause-effect relationships between independent variables and the outcome to be inferred. Additionally, health variables were self-reported and, consequently, a certain existing disease could have been forgotten or some information could have been misreported. Moreover, the bias of survival, inherent in cross-sectional studies, cannot be ignored as an explanation for the results found, as only older adult individuals with a more adequate lifestyle reach this age as a rule.

The main positive aspect of the present study was the sample size $(n=343)$ as a large sample was included, sufficient for the proposed statistical analyses. Additionally, studies with octogenarians are still scarce in Brazil, due to the difficulty to contact these individuals.

Longitudinal studies can contribute to a better understanding of the direction of the associations found. Furthermore, home studies could also find important data on this theme.

Self-perception of health can be considered as a good indicator of the health condition of older adults. In this sense, to show the variables that interfere with a positive self-perceived health of octogenarians participating in community groups is essential for the overall health surveillance of this age group and it helps to improve health actions. Moreover, this knowledge can also help to strengthen strategies for a more frequent use of health services that offer opportunities of social interaction and health promotion among older adults, considering the positive associations found between positive self-perceived health, the practice of physical activities during leisure time and having a job (paid or not). This increases the reduction in costs of hospitalizations and health treatments, which are very frequent in this older population.

In conclusion, working, smoking, and being physically active during leisure time were positively associated with self-perceived health in octogenarians participating in community groups in the city of Florianópolis. In contrast, having arthritis/rheumatism, diabetes and cardiovascular diseases and using medication were inversely associated with positive self-perceived health.

\section{Author contributions}

R. R. Krug contributed to data collection, writing, project planning, data interpretation, draft preparation, critical review of the content and approval of the final version. I. J. C. Schneider contributed to the writing, project planning, data interpretation, draft preparation, critical review of the content and approval of the final version. S. C. Confortin, D. L. Antes and M. W. C. Giehl contributed to the writing, draft preparation, critical review of the content and approval of the final version. M. A. Lopes and G. Z. Mazo contributed to data collection, writing, critical review of the content and approval of the final version. A. J. Xavier and E. d'Orsi contributed to the project planning, data interpretation, critical review of the content and approval of the final version. 


\section{References}

1. Gottlieb MGV,Schwanke CHA, Gomes I, Cruz IBM. Aging and Longevity in Rio Grande do Sul: a historic, ethnic and morbi-mortality profile of older adults. Rev BrasGeriatr Gerontol 2011;14(2):9-20.

2. Kirkwood TBL. A systematic look at an old problem: as life expectancy increases, a systemsbiology approach is needed to ensure that we have a healthy old age. Nature. 2008;451(7): 644-7.

3. Instituto Brasileiro de Geografia e Estatística. A summary of social indicators - An analysis of living conditions of the Brazilian population. Rio de Janeiro: Brazilian Institute of Geography and Statistics; 2010. Available at: http://www.ibge.gov.br/ cidadesat/topwindow.htm?1> acesso em: 26 de junho de 2011.

4. Pagotto V, Bachion MM, Silveira EA. Self-assessment of health by older adult Brazilians: a systematic review of the literature. Rev Panam Salud Publica 2013; 33(4):302-10.

5. Pavão ALB, Werneck GL, Campos MR. Self-assessment of health status and association with socio-demographic factors, life habits and morbidity in the population: a national survey. Cad. Saúde Pública 2013; 29(4):723-34.

6. Brasil. Norma Operacional Básica da Assistência Social (NOB/SUAS). Brasília: Unified Social Welfare System (SUAS); 2005. Available at: http://www.assistenciasocial.al.gov.br/ sala-de-imprensa/arquivos/NOB-SUAS.pdf> acesso em: 16 de setembro de 2016.

7. Liu L, Newschaffer CJ. Impact of social connections on risk of heart disease, cancer, and all-cause mortality among elderly Americans: findings from the Second Longitudinal Study of Aging (LSOA II). Arch Gerontol Geriatr. 2011; 53(2):168-73.

8. Ware JE Jr, Kosinski M, Keller SD. A 12- item Short- Form Health Survey: construction of scales and preliminary tests of reliability and validity.Med Care 1996; 34(3):220-33.

9. Confortin SC, Giehl MWC, Antes DL, Schneider IJC, d'Orsi E. Positive self-perceived health in older adults: a population study in Southern Brazil. Cad. Saúde Pública 2015; 31(5):1049-60.

10. Babor TF, Higgins-Biddle JC, Saunders JB, Monteiro MG. Audit: The Alcohol Use Disorders Identification Test. Second Edition. Word Health Organization: Genebra; 1993. Pg.41.

11. Mazo GZ, Benedetti TRB. Adaptation of the International Physical Activity Questionnaire for older adults. Rev Bras Cineantropom Desemp Hum 2010;12(6):480-4.

12. Moschny A, Platen P, KlaaBen-Mielke R, Trampich U, Hinrichs T. Barriers to physical activity in older adults in Germany: a cross-sectional study. Int J Behav Nutr Phys Activity 2011;8(2):121-31.

13. Loyola Filho AI, Firmo JOA, Uchoa E, Lima-Costa MF. Factors associated with negative self-assessed health among hypertensive and/or diabetic older adults: results from the Bambuí project. Rev Bras Epidemiol 2013; 16(3):559-71.

14. Guccione AA, Felson DT, Anderson JJ, Anthony JM, Zhang Y, Wilson PW, et al. The effects of specific medical conditions on the functional limitations of elders in the Framingham Study. Am J Public Health1994; 84(3):351-8.

15. Capri M, Salvioli S, Monti D, Caruso C, Candore G, Vasto S, et al. Human longevity within an evolutionary perspective: The peculiar paradigm of a post-reproductive genetics. Exp Gerontol 2008; 43(2) 53-60.

16. Mazo GZ, Mota AJ, Gonçalves LHT, Matos MG. Physical activity level, health conditions and socio-demographic characteristics of female older adult Brazilians. Rev Port Cie Desp 2005; 5(2):202-12.

17. Benedettti TRB, Petroski EL, Gonçalves LHT. The profile of older adults in the city of Florianópolis: final report. Florianópolis: Pallotti; 2004. 88p.

18. Loyola Filho AI, Uchoa E, Lima-Costa MF. Population-based epidemiological study on the use of medication among older adults in the Metropolitan Region of Belo Horizonte, Minas Gerais, Brazil. Cad Saúde Pública 2006; 22(12):2657-67.

19. Linjakumpu T, Hartikainen S, Klaukka T, Veijola J, Kivelä SL, Isoaho R. Use of medications and polypharmacy are increasing among the elderly.J Clin Epidemiol 2002; 55(8):809-17.

20. Borim FSA, Barros MBA, Neri AL. Self-assessment of health in older adults: a populationbased study in the city of Campinas, São Paulo, Brazil. Cad Saúde Pública 2012; 28(4):769-80.

21. Robert AS, Cherepanov D, Palta M, Dunham NC, Feeny D, Fryback DG. Socioeconomic status and age variations in health-related quality of life: results from the National Health Measurement Study. J Gerontol B Psychol Sci Soc Sci 2009; 64:S378-89. 
22. Travassos C, Viacava F, Laguardia J. Health Supplements in the National Household Sample Survey (PNAD) in Brazil. Rev Bras Epidemiol 2008; 11(suppl 1):98-112.

23. Lima-Costa MF, Barreto SM, Firmo JOA, Uchôa E. Socioeconomic position and health in a population of Brazilian elderly: the Bambuí Health and Aging Study (BHAS). Rev Panam Salud Publica 2003; 13(6):387-94

24. Peixoto SV,Firmo JO,Lima-Costa MF. Factors associated to smoking habit among older adults (The Bambuí Health and Aging Study). Rev Saude Pública.2005; 39(5):746-53.

25. Costa MFFvL, Peixoto SV, César CC, Malta DC, Moura EC. Health behavior among hypertensive older adults, Brazil, 2006. Rev. Saúde Pública. 2009; 43(2):18-26.

26. Azevedo RCS, Higa CMH, Assumpção ISMA, Frazatto CRG, Fernandes RF, Goulart W et al. Therapeutic group for smokers: results after two years of follow-up. Rev. Assoc. Med. Bras. 2009; 55(5):593-6.

27. Siqueira FV, Facchini LA, Piccini RX, Tomasi E, Thumé E, Silveira DS, et al. Physical activity in adults and older adults living in areas covered by primary health units of cities in Southern and Northeastern Brazil. Cad Saude Publica.2008; 24(1):39-54.

28. Lee IM, Shiroma EJ, Lobelo F, Puska P, Blair SN, Katzmarzyk PT. Effect of physical inactivity on major non-communicable diseases worldwide: an analysis of burden of disease and life expectancy. Lancet 2012; 380(9838):219-29.

29. Hamer M, Lavoie KL, Bacon SL. Taking up physical activity in later life and healthy ageing: the English longitudinal study of ageing. British J Sports Med2014; 48(3):6-15.

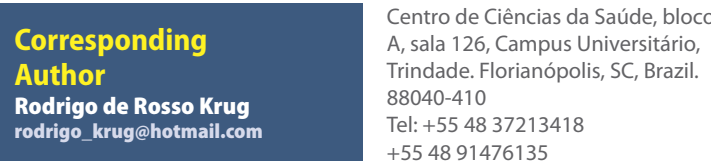

Received 19/02/2016 